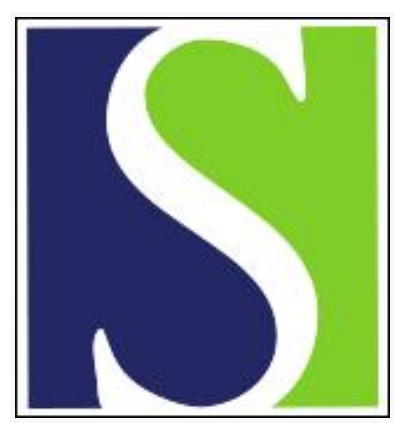

Scand J Work Environ Health 1987;13(2):81-93

https://doi.org/10.5271/sjweh.2075

Issue date: Apr 1987

Pharmacokinetics of organic solvent vapors in relation to their toxicity.

by Sato A, Nakajima T

This article in PubMed: www.ncbi.nlm.nih.gov/pubmed/3299685

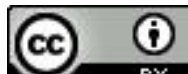




\title{
Pharmacokinetics of organic solvent vapors in relation to their toxicity
}

\author{
by Akio Sato, MD, PhD, ${ }^{1}$ Tamie Nakajima, $\mathrm{PhD}^{2}$
}

\begin{abstract}
SATO A, NAKAJIMA T. Pharmacokinetics of organic solvent vapors in relation to their toxicity. Scand $J$ Work Environ Health 13 (1987) 81-93. The volatility and lipophilicity by which organic solvents are distinct from other chemicals constitute a characteristic pharmacokinetic feature. They enter a living body by inhalation, preferentially distribute in the adipose tissue, and are eliminated by both expiration and metabolic degradation. This review article is centered on experimental studies conducted by the authors and their co-workers, and it deals with (i) pharmacokinetic principles, (ii) partition coefficients in relation to toxicity, (iii) significance of metabolism in the development of organic solvent toxicity, and (iv) environmental factors that alter the metabolism and toxicity of solvents.
\end{abstract}

Key terms: partition coefficient, metabolism, dietary factors, ethanol.

A biologically toxic substance elicits its action by binding to biological macromolecules such as membranes, enzymes and deoxyribonucleic acid (DNA) in the target tissue. The nature of macromolecules with which the substance or its metabolites associate determines the type of toxicity, whereas the intensity and duration of toxic responses are dependent on the extent of the association, which is determined by the concentration at the site of action $(17,30)$. Therefore, the quantitative description of absorption, distribution, metabolism, and excretion, ie, the pharmacokinetics, of foreign chemical compounds constitute an essential part of toxicology.

\section{Principles of pharmacokinetics for organic solvent vapors}

Most organic solvents are highly volatile. They, therefore, enter a living body chiefly through the respiratory route, some fractions being excreted through the same route. The amount entering the body through the skin is considerable when the skin is directly in contact with the solvents in liquid form (11, $12,14,29,45)$ but is negligible when the skin is exposed to air containing solvent vapors, in most cases, amounting only to a few percent of that entering through the lungs $(41,43)$.

Figure 1 illustrates the transfer of organic solvent vapors in a living system (51). When inhaled, the vapors in lung alveoli diffuse into the blood according

Department of Environmental Health, Medical University of Yamanashi, Tamaho, Yamanashi 409-38, Japan.

2 Department of Hygiene, Shinshu University School of Medicine, Asahi, Matsumoto 390, Japan.

Reprint requests to: Professor A Sato, Department of Environmental Health, Medical University of Yamanashi, Tamaho, Yamanashi 409-38, Japan. to Henry's law. They are transported throughout the body by the circulatory system and distributed among the various body tissues. Some portion of the vapor is enzymatically transformed into metabolites with polar functions and finally excreted into the urine after being conjugated with water-soluble molecules such as glucuronic acid and sulfuric acid. Some fractions return to the lungs via the venous blood and contribute to the equilibration process occurring at the alveoli. During inhalation (saturation process), the alveolar, arterial, tissue, and venous tensions gradually rise towards eventual equilibrium throughout the body. When the vapor is removed from the inhaling air (desaturation process), the reverse occurs and the tensions gradually fall to zero.

The most important factor controlling pulmonary absorption or excretion is the partition coefficient between air and blood, which is defined as the concentration ratio of a vapor between blood and air at a defined temperature and is numerically equal to the Ostwald solubility coefficient at the temperature defined $(1,28,47)$.

Table 1 shows the partition coefficients of some representative organic solvents into water, blood and oil $(46,47)$. The largest coefficient value of an organic solvent into blood was 2000 for methanol, and the

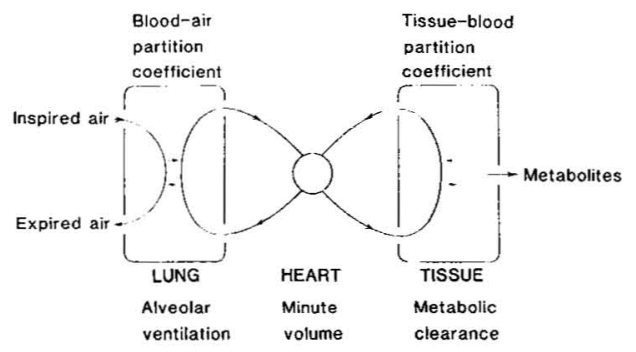

Figure 1. Transfer of organic solvents in a biological system (5i). 
Table 1. Partition coefficients of organic solvents into blood, water and oil at $37^{\circ} \mathrm{C}(46,47)$.

\begin{tabular}{|c|c|c|c|}
\hline Solvents & Blood & Water & Oil \\
\hline Benzene, $\mathrm{C}_{6} \mathrm{H}_{6}$ & 7.8 & 2.8 & 492 \\
\hline Toluene, $\mathrm{C}_{6} \mathrm{H}_{5} \mathrm{CH}_{3}$ & 15.6 & 2.2 & 1470 \\
\hline o-Xylene, $\mathrm{C}_{6} \mathrm{H}_{4}\left(\mathrm{CH}_{3}\right)_{2}$ & 31.1 & 2.6 & 4360 \\
\hline$m$-Xylene, $\mathrm{C}_{6} \mathrm{H}_{4}\left(\mathrm{CH}_{3}\right)_{2}$ & 26.4 & 1.7 & 3840 \\
\hline p-Xylene, $\mathrm{C}_{6} \mathrm{H}_{4}\left(\mathrm{CH}_{3}\right)_{2}$ & 37.6 & 1.6 & 3690 \\
\hline Ethylbenzene, $\mathrm{C}_{6} \mathrm{H}_{5} \mathrm{CH}_{2} \mathrm{CH}_{3}$ & 28.4 & 1.7 & 3790 \\
\hline Propylbenzene, $\mathrm{C}_{6} \mathrm{H}_{4} \mathrm{CH}_{2} \mathrm{CH}_{2} \mathrm{CH}_{3}$ & 47.0 & 1.3 & 9780 \\
\hline Cumene, $\mathrm{C}_{6} \mathrm{H}_{5} \mathrm{CH}\left(\mathrm{CH}_{3}\right)_{2}$ & 37.0 & 1.4 & 6220 \\
\hline Styrene, $\mathrm{C}_{6} \mathrm{H}_{5} \mathrm{CH}=\mathrm{CH}_{2}$ & 51.9 & 4.7 & 5470 \\
\hline Dichloromethane, $\mathrm{CH}_{2} \mathrm{Cl}_{2}$ & 9.7 & 7.2 & 152 \\
\hline Chloroform, $\mathrm{CHCl}_{3}$ & 10.3 & 3.5 & 401 \\
\hline Carbon tetrachloride, $\mathrm{CCl}_{4}$ & 2.4 & 0.3 & 361 \\
\hline 1,1-Dichloroethane, $\mathrm{CH}_{3} \mathrm{CHCl}_{2}$ & 4.7 & 2.7 & 187 \\
\hline 1,2-Dichloroethane, $\mathrm{CH}_{2} \mathrm{ClCH}_{2} \mathrm{Cl}$ & 19.5 & 11.3 & 447 \\
\hline 1,1,1-Trichloroethane, $\mathrm{CH}_{3} \mathrm{CCl}_{3}$ & 3.3 & 0.9 & 356 \\
\hline 1,1,2-Trichloroethane, $\mathrm{CH}_{2} \mathrm{ClCHCl}_{2}$ & 38.6 & 17.1 & 2270 \\
\hline 1,1,1,2-Tetrachloroethane, $\mathrm{CH}_{2} \mathrm{ClCCl}_{3}$ & 30.4 & 5.5 & 4310 \\
\hline $\begin{array}{l}\text { 1,1,2,2-Tetrachloroethane, } \\
\mathrm{CHCl}_{2} \mathrm{CHCl}_{2}\end{array}$ & 121 & 35.7 & 13200 \\
\hline $\begin{array}{l}\text { cis-1,2-Dichloroethylene, } \\
\mathrm{CHCl}=\mathrm{CHCl}\end{array}$ & 9.2 & 2.9 & 270 \\
\hline $\begin{array}{l}\text { trans-1,2 } \\
\mathrm{CHCl}=\mathrm{C}\end{array}$ & 5.8 & 2.1 & 189 \\
\hline Trichloroethylene, $\mathrm{CHCl}=\mathrm{CCl}_{2}$ & 9.5 & 1.3 & 718 \\
\hline Tetrachloroethylene, $\mathrm{CCl}_{2}=\mathrm{CCl}_{2}$ & 13.1 & 0.4 & 1920 \\
\hline Monochlorobenzene, $\mathrm{C}_{6} \mathrm{H}_{5} \mathrm{Cl}$ & 30.8 & 4.1 & 3760 \\
\hline o.Dichlorobenzene, $\mathrm{C}_{6} \mathrm{H}_{4} \mathrm{Cl}_{2}$ & 423 & 9.0 & 39900 \\
\hline$m$-Dichlorobenzene, $\mathrm{C}_{6} \mathrm{H}_{4} \mathrm{Cl}_{2}$ & 201 & 5.5 & 27100 \\
\hline Methyl alcohol, $\mathrm{CH}_{3} \mathrm{OH}$ & 2100 & 2690 & 56 \\
\hline Ethyl acetate, $\mathrm{CH}_{3} \mathrm{COOCH}_{2} \mathrm{CH}_{3}$ & 222 & 145 & 479 \\
\hline Diethyl ether, $\mathrm{CH}_{3} \mathrm{CH}_{2} \mathrm{OCH}_{2} \mathrm{CH}_{3}$ & 14.0 & 13.0 & 64 \\
\hline Acetone, $\mathrm{CH}_{3} \mathrm{COCH}_{3}$ & 245 & 395 & 86 \\
\hline Methyl ethyl ketone, $\mathrm{CH}_{3} \mathrm{COCH}_{2} \mathrm{CH}_{3}$ & 202 & 254 & 263 \\
\hline $\begin{array}{l}\text { Methyl n-butyl ketone, } \\
\mathrm{CH}_{3} \mathrm{CO} \mathrm{CH}_{2} \mathrm{CH}_{2} \mathrm{CH}_{2} \mathrm{CH}_{3}\end{array}$ & 127 & 111 & 1640 \\
\hline $\begin{array}{l}\text { Methyl isobut } \\
\mathrm{CH}_{3} \mathrm{COCH}_{2} \mathrm{CH}\end{array}$ & 90 & 79 & 926 \\
\hline
\end{tabular}

Table 2. Partition coefficients of trichloroethylene in various body tissues of rats and humans (53).

\begin{tabular}{lc}
\hline & Partition coefficient \\
\cline { 2 - 2 } Rats & \\
Blood : air & 25.8 \\
Lung : blood & 1.0 \\
Heart : blood & 1.1 \\
Kidney : blood & 1.6 \\
Liver : blood & 1.7 \\
Brain : blood & 1.3 \\
Testis : blood & 0.7 \\
Spleen : blood & 1.2 \\
Muscle : blood & 0.6 \\
Fat : blood & 25.6 \\
Humans : & \\
Blood : air & 9.5 \\
Fat : blood & 68.0 \\
\hline
\end{tabular}

smallest was 2 or 3 for carbon tetrachloride and 1,1,1-trichloroethane.

The amount of a vapor taken up by various body tissues (ie, distribution) depends on the affinity of the vapor for each tissue. Table 2 shows the partition coefficients of trichloroethylene into the various body tissues of rats (53). The coefficients between blood and tissues were almost unity for all tissues other than fat. The value for fat tissue was very high, almost 20 times as high as the values for the other tissues. Because almost all the organic solvents are highly lipophilic by nature, body fat greatly affects their uptake, distribution, and excretion. For example, body fat content is different between men and women. Women normally have a relatively larger volume of body fat than do average men despite their smaller statue. This difference may result in the different disposition of these fat-soluble substances between the sexes. In fact, our kinetic study has revealed that the rate of benzene elimination is slower in women than in men and that the slower elimination in women is primarily due to the bulky distribution of fat tissue (52). Women are considered to be more susceptible to benzene-induced hemotoxicity (6). The difference in body fat content between the sexes provides a plausible explanation for the sex-related difference in susceptibility to benzene toxicity.

As absorbed organic solvents are transported chiefly via the blood stream, blood flow (perfusion rate) is another determinant of the distribution of vapors in each tissue. In most pharmacokinetic models proposed so far, the whole body is generally divided into three tissue groups with respect to the solubility of vapors in each tissue and the rate of blood perfusion through the tissue $(13,15,51)$. About $75 \%$ of the cardiac output is delivered to a group of tissues that comprises less than one-tenth of the total body volume. This group is designated as the vessel-rich tissue group. The tissue : blood partition coefficients for the vessel-rich group are almost unity for most solvents. The muscle group, consisting of muscles and skin, occupies $50 \%$ of the body volume and receives $18 \%$ of the cardiac output under resting conditions. The partition coefficients for the muscle group are also almost unity. Fat tissue and white bone marrow, which roughly comprise $20 \%$ of the body volume and receive $5 \%$ of the cardiac output, are separately classified into the third tissue group, usually referred to as the fat group, because most of the organic solvents have a very high affinity for these tissues.

With lungs added to these three tissue groups, we were able to construct a physiological four-compartment model for the transfer of organic solvent vapors in a living body (unpublished data). Figure 2 shows the basic feature of this model, in which pulmonary ventilation was assumed to be continuous in spite of the cyclic nature of respiration. Any process of vapor transfer in the system was assumed to be describable by first-order kinetics except for metabolic disappearance, a pathway which is saturable (zero order) at a high concentration. An equilibrium was assumed to exist between the vapor in a compartment and in blood issuing from the compartment. In addition it was 
assumed that the loss of vapors by metabolism occurs only in the compartment of the vessel-rich group with negligible loss of vapors in unchanged form through any routes other than expired breath. On the basis of these assumptions, we can express the process occurring in the system in the form of simultaneous differential equations as follows: during the inhalation of a vapor of constant concentration (saturation),

$$
\begin{aligned}
V_{1} \frac{d c_{1}}{d t}= & f_{1} c_{0}+\frac{f_{2}}{\lambda_{2}} c_{2}+\frac{f_{3}}{\lambda_{3}} c_{3}+\frac{f_{4}}{\lambda_{4}} c_{4} & \\
& -f_{1} c_{1}-\left(f_{2}+f_{3}+f_{4}\right) \lambda_{1} c_{1}, & \text { equation 1 } \\
V_{2} \frac{d c_{2}}{d t}= & f_{2} \lambda_{1} c_{1}-\frac{f_{2}}{\lambda_{2}} c_{2}-\frac{V m a x \cdot c_{2}}{K m+c_{2}}, & \text { equation 2 } \\
V_{3} \frac{d c_{3}}{d t}= & f_{3} \lambda_{1} c_{1}-\frac{f_{3}}{\lambda_{3}} c_{3}, & \text { equation 3 }
\end{aligned}
$$

and

$$
V_{4} \frac{d c_{4}}{d t}=f_{4} \lambda_{1} c_{1}-\frac{f_{4}}{\lambda_{4}} c_{4},
$$

equation 4

and after the cessation of inhalation (desaturation), equations 1 through 4 hold except that $c_{0}=0$.

When the assumption of first-order metabolism is applicable (a case in which the concentration in inhaled air is sufficiently low), the last term of equation 2 can be replaced by $k c_{2}$ ( $k=$ the rate constant for metabolic disappearance). In this case, equations 1 through 4 can be arranged into a linear differential equation of fourth order, which is solved into the general solution for $\mathrm{c}_{i}(i=1-4)$ as follows: for saturation,

$$
\begin{aligned}
c_{i}= & A_{i 1}\left(1-e^{-\alpha_{1} t}\right)+A_{i 2}\left(1-e^{-\alpha_{2} t}\right) \\
& +A_{i 3}\left(1-e^{-\alpha_{3} t}\right)+A_{i 4}\left(1-e^{-\alpha_{4} t}\right),
\end{aligned}
$$

and after inhalation (desaturation),

$$
c_{i}=A^{\prime}{ }_{i 1} e^{-\alpha_{1} t}+A^{\prime}{ }_{i 2} e^{-\alpha_{2} t}+A^{\prime}{ }_{i 3} e^{-\alpha_{3} t}+A^{\prime}{ }_{i 4} e^{-\alpha_{4} t},
$$

where $A_{i j}$ and $A^{\prime}{ }_{i j}(j=1-4)$ are constants determined by the initial conditions at $t=0$. It would be difficult to solve the differential equations algebraically, but the equations can be solved numerically with computer programs to simulate the expected pharmacokinetic behavior of each solvent (unpublished data).

As is suggested by the preceding description, any physiological or environmental factor that alters respiratory and cardiovascular functions produces a significant effect on the uptake, distribution and elimination of volatile substances. The physical factor is one of the most important. In fact, Astrand (2) has demonstrated that physical exercise markedly enhances the uptake of organic solvents in the body. However, the exercise changes the distribution of blood flow to each tissue, increasing the perfusion rates through the muscles and adipose tissues on the one hand and decreasing the blood flow through the liver on the other. Thus strenuous physical work can result in reduced availability of the chemicals to metabolic clearance (2).

\section{Partition coefficients of organic solvents in relation to toxicity}

Partition coefficients of biologically active compounds between blood and air, oil and air, and oil and water have long been used for the study of structure-activity relationships, ever since the Meyer-Overton theory was proposed in 1933 that partitioning of narcotics between oil and water would parallel the way they partition between an aqueous exobiophase and a lipophilic site of action in the biophase (20). For example, Miller et al (33) have reported a linear relationship between the $50 \%$ effective dose $\left(E D_{50}\right)$ and the olive oil : air partition coefficients of 20 narcotics of various types.

Partition coefficients of organic solvent vapors into water, blood, or oil can be measured easily with a simple vial-equilibration technique (46), which does not require any direct measurement of the concentration either in the air or in the liquid phase, but only the gas chromatographic peak heights or areas of the air in the sample (in which a test material is contained) and reference vessels (containing no material). This method is applicable to partition measurement of every organic solvent as long as it is volatile and is sensitive to gas chromatographic analysis.

Every organic solvent has anesthetic action to some extent owing to its high lipophilicity. As has already been mentioned, the partition coefficient between

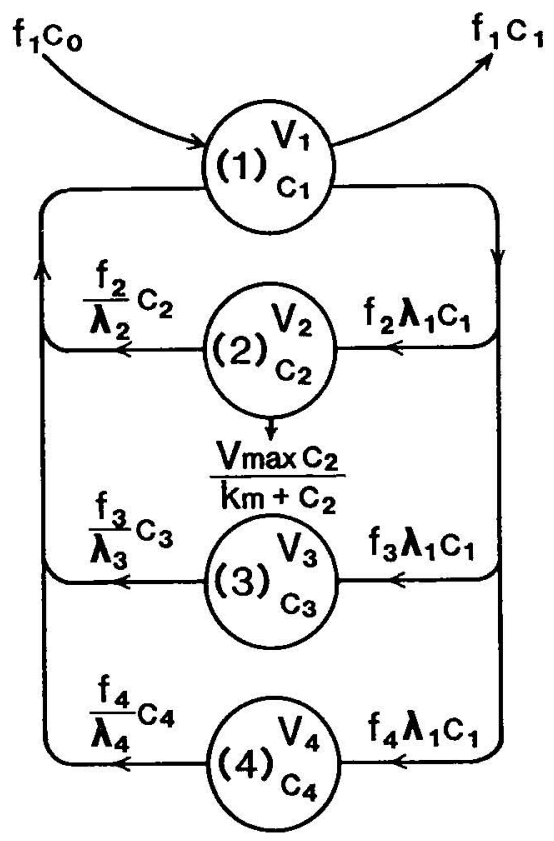

Figure 2. A four-compartment model, lungs (1), vessel-rich tissue group (VRG) (2), muscle group (MG) (3) and fat tissue group (FG) (4), for organic solvent transfer in a living body (unpublished model). [V $i(i=1-4)=$ volume of compartment $i, \mathrm{c}_{0}=$ concentration in inspired air, $c_{i}(i=1-4)=$ concentration in compartment $i, \mathrm{f}_{1}=$ alveolar ventilation, $\mathrm{f}_{i}(i=2-3)=$ blood flow through compartment $i, \lambda_{1}=$ blood : air partition coefficient, $\lambda_{2}=$ VRG : blood partition coefficient, $\lambda_{3}=M G$ : blood partition coefficient, $\lambda_{4}=F G$ : blood partition coefficient, $V_{\max }=$ maximum velocity of enzymic reaction, $\mathrm{km}=$ Michaelis constant] 
blood and air is one of the most important factors controlling the uptake of inhaled organic solvent vapors. Therefore, if a biological response induced by organic solvents is based on a common mechanism, as is the case of anesthetic action, the magnitude of response may parallel the amount absorbed in the body, ie, the partition coefficient between blood and air. In fact, Morgan et al (34) have reported that there is a clear linear relationship between anesthetic potency and the blood serum : air partition coefficient for nine chlorinated aliphatic hydrocarbons.

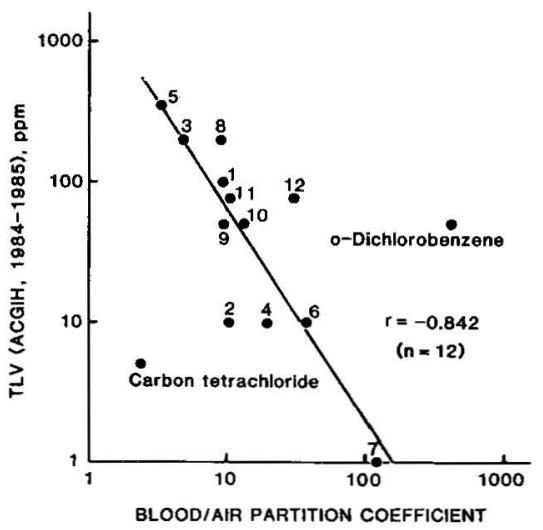

Figure 3. Relationship between the threshold limit values (TLV) of various solvents and the blood : air partition coefficient (47). $(1$ = dichloromethane, 2 = chloroform, 3 = 1,1-dichloroethane, $4=1,2$-dichloroethane, $5=1,1,1$-trichloroethane, $6=1,1,2$-trichloroethane, $7=1,1,2,2$-tetrachloroethane, $8=$ cis-1,2-dichloroethylene, $9=$ trichloroethylene, $10=$ tetrachloroethylene, 11 = 1,2-dichloropropane, 12 = monochlorobenzene)

Table 3. Respiratory and metabolic clearances of organic solvent vapors absorbed in the human body (theoretically calculated from the data in references 38 and 53).

\begin{tabular}{lrrrrr}
\hline \multirow{2}{*}{ Solvent vapors } & \multicolumn{2}{c}{$\begin{array}{c}\text { Respiratory } \\
\text { clearance }\end{array}$} & & \multicolumn{2}{c}{$\begin{array}{c}\text { Metabolic } \\
\text { clearance }\end{array}$} \\
\cline { 2 - 3 } \cline { 6 - 7 } & I/h & $\%$ & & I/h & $\%$ \\
\hline Benzene & 43 & 36 & & 75 & 64 \\
Toluene & 22 & 18 & & 100 & 82 \\
$m$-Xylene & 13 & 10 & & 116 & 90 \\
Styrene & 6 & 4 & & 157 & 96 \\
Dichloromethane & 35 & 18 & & 157 & 82 \\
Chloroform & 33 & 23 & & 108 & 77 \\
Carbon tetrachloride & 140 & 93 & & 11 & 7 \\
1,1-Dichloroethane & 72 & 41 & & 105 & 59 \\
1,2-Dichloroethane & 17 & 12 & & 130 & 88 \\
1,1,1-Trichloroethane & 102 & 97 & & 3 & 3 \\
1,1,2-Trichloroethane & 9 & 7 & & 116 & 93 \\
1,1,1,2-Tetrachloroethane & 11 & 20 & & 45 & 80 \\
1,1,2,2-Tetrachloroethane & 3 & 4 & 73 & 96 \\
Trichloroethylene & 35 & 25 & & 104 & 75 \\
Tetrachloroethylene & 26 & 90 & & 3 & 10 \\
\hline
\end{tabular}

a Respiratory clearance is calculated on the assumption of an alveolar ventilation of $336 \mathrm{l} / \mathrm{h}$.
We plotted the threshold limit value (TLV) listed by the American Conference of Governmental Industrial Hygienists (3) for 12 chlorinated organic solvents against the corresponding blood : air partition coefficient (table 1) on a log-log scale (figure 3) (47). The TLV was inversely related to the partition coefficient, with the exception of that for carbon tetrachloride and $o$-dichlorobenzene. (A low TLV is recommended for a hydrocarbon that is readily soluble in the blood.) Carbon tetrachloride significantly deviated from linearity. Because carbon tetrachloride-induced hepatotoxicity is caused not by the substance itself, but by its metabolite, it is clear that the toxicity is not simply dependent on the blood : air partition coefficient. The rate of metabolism, ie, the rate of active metabolite formation, is a much more important determinant of the toxicity (35). $o$-Dichlorobenzene also deviated from linearity, but in the opposite direction of carbon tetrachloride. This finding shows that a higher TLV is recommended for this chlorobenzene than its partition coefficient would indicate. It is our opinion that the TLV for $o$-dichlorobenzene should be lowered in the future. The same TLV, $100 \mathrm{ppm}$, is recommended for both toluene and xylene. Both solvents are potent central nervous system depressants, and their toxicities are considered on the basis of a common mechanism, ie, anesthetic action. The partition coefficient of xylene is almost twice as high as that of toluene (table 1). In addition, xylene [vapor pressure $6 \mathrm{~mm} \mathrm{Hg}$ $(0.8 \mathrm{kPa})]$ is less volatile than toluene $[24 \mathrm{~mm} \mathrm{Hg}$ $(3.2 \mathrm{kPa})]$. Taking these facts into consideration, the TLV for xylene should also be reevaluated in the future.

There is no simple relation between the partition coefficient and chemical structure or between the partition coefficient and physical properties such as molecular weight and boiling point (table 1). In general, however, a compound with a high molecular weight or boiling point tends to have a high partition coefficient value for both blood and oil, and conversely, a low value for water. For example, for alkylbenzene congeners, ie, benzene, toluene, ethylbenzene, and propylbenzene, there was a linear relationship on a log-log scale between molecular weight and the blood : air partition coefficient $(r=1.00)$, boiling point and blood : air $(r=1.00)$, molecular weight and water : air $(r=-0.99)$, boiling point and water : air $(r=-0.98)$, molecular weight and oil : air $(r=1.00)$, and boiling point and oil : air $(r=0.99)$.

Among the three isomers of xylene, $o$-xylene was more soluble in water than the other two isomers (an ortho effect) (table 1), but the partition into blood or oil did not differ so much as did the partition into water among these three isomers. Concerning 1,2-dichloroethylene, the cis form was more soluble in water, blood, and oil than the trans form. However, the difference between the two stereoisomers was small. In contrast, the difference between the partition coefficients of structural isomers of chlorinated ethanes was 
striking. The isomer with a high boiling point (1,2-dichloro-, 1,1,2-trichloro-, or 1,1,2,2-tetrachloroethane) was much more soluble in all of the three liquids water, blood and oil than the corresponding isomer with a low boiling point (1,1-dichloro-, 1,1,1trichloro- or 1,1,1,2-tetrachloroethane, respectively). In other words, the chlorinated ethanes with chlorine atoms on both carbon atoms (1,2-type chloroethanes) were much more soluble in water, blood, and oil than those having chlorines preferentially on either carbon atom of ethane (1,1-type chloroethanes). These findings suggest that the position of the substituted chlorine atoms greatly affects the pharmacokinetic profile of the chlorinated ethane. The 1,2-type has been believed to be more toxic than the 1,1-type of chloroethane $(16,25)$. These findings also indicate the importance of solubility coefficients in the evaluation of organic solvent toxicity.

\section{Significance of metabolism in the development of organic solvent toxicity}

\section{Pulmonary and metabolic clearances}

The main routes by which a living body eliminates absorbed organic solvents are urinary and pulmonary excretion. Generally, a large percentage of an absorbed solvent undergoes metabolic degradation to be excreted in urine, and the remaining smaller portion is eliminated unchanged through the respiratory route. Table 3 shows the respiratory and metabolic clearances calculated theoretically from our experimental results (38, 53). Metabolic clearance varied from one solvent to another. For example, benzene is somewhat resistant to the enzyme attack, $40 \%$ being eliminated unchanged through the lungs, whereas toluene is subject to metabolic degradation, about $80 \%$ of the absorbed toluene being excreted in the urine as metabolites.

The liver is the major metabolic site for foreign compounds. Hepatic metabolism is important because $25 \%$ of cardiac output flows through the liver. The following discussion of the importance of metabolic clearance in relation to alveolar clearance uses trichloroethylene and 1,1,1-trichloroethane as examples. The blood : air partition coefficient of trichloroethylene is about three times as large as that of 1,1,1-trichloroethane, whereas the oil : blood partition coefficient of the chloroethane is 1.4 times larger than that of the chloroethylene. These facts suggest that 1,1,1-trichloroethane is absorbed to a less extent, but that, once absorbed, it is distributed more readily in adipose tissues and it remains there for a longer time than does trichloroethylene. The partition coefficient between blood and air also tells us that the chloroethane is more subject to respiratory elimination than the chloroethylene. In addition, we may predict from the data in table 3 that absorbed 1,1,1-trichloroethane is exclusively eliminated unchanged in the expired air, whereas trichloroethylene is mainly excreted in the
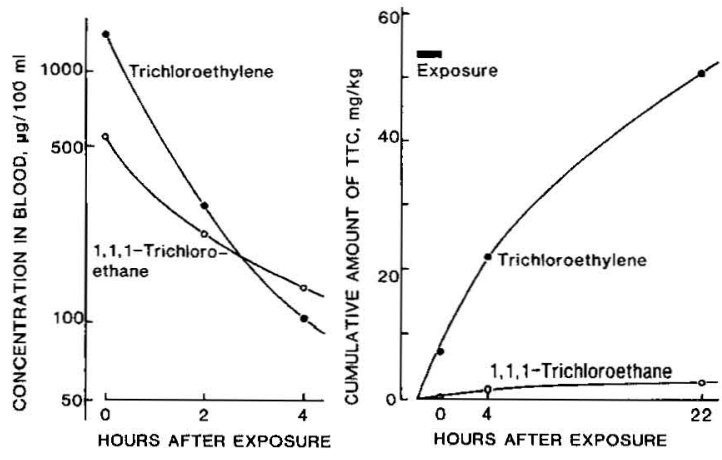

Figure 4. Decay curves of trichloroethylene and 1,1,1trichloroethane (left) and urinary excretion of total trichloro compounds (TTC) (right) after a 2-h inhalation exposure of rats to $500 \mathrm{ppm}$ of trichloroethylene and 1,1,1-trichloroethane (unpublished data).

urine after being transformed into water-soluble metabolites.

Figure 4 shows the decay of trichloroethylene and 1,1,1-trichloroethane from the blood, together with the urinary excretion of metabolites after rats were exposed to $500 \mathrm{ppm}$ of each solvent for $2 \mathrm{~h}$ (unpublished data). The trichloroethylene concentration measured at the end of exposure was about twice as high as that of 1,1,1-trichloroethane. However, trichloroethylene disappeared quickly from the body, and $4 \mathrm{~h}$ later the concentration was reversed between the two solvents. In accordance with this occurrence rats exposed to trichloroethylene excreted a much larger amount of metabolites than did the rats exposed to 1,1,1-trichloroethane. These findings clearly indicate that the biological half-time of 1,1,1-trichloroethylene is longer than that of trichloroethylene and also that, as expected, a large part of absorbed trichloroethylene is excreted as metabolites, whereas 1,1,1-trichloroethane hardly undergoes metabolic degradation. Thus knowledge of the partition coefficients, together with the rates of metabolism in vitro, enables us to predict, to some degree, the pharmacokinetic profiles of a variety of organic solvents.

The rate of volatile hydrocarbon metabolism in vitro can be assayed with a vial-equilibration technique (48). A substrate $(q \mathrm{~mol})$ is incubated together with a mixture of enzyme and a cofactor in a small airtight vial for a period of time $(t)$. No direct measurement of the product formed or of the substrate disappearing is needed; only the ratio of the gas chromatographic peak height $(h$ ') obtained from the air phase in the sample vessel (cofactors included) to that $(h)$ from the reference vessel (cofactors excluded) is necessary to calculate the rate of enzymic reaction $(v)$, ie, $v=q$ $\left(1-h^{\prime} / h\right) / t$. This method is simple but useful for a variety of metabolism studies as long as the substrates are volatile and sensitive to gas chromatographic analysis. 


\section{Metabolism in relation to toxicity}

Metabolic transformation of foreign chemical compounds is important in two respects. First, it plays a decisive role in determining the biological half-time of the chemical. Second, the biotransformation sometimes results in the production of highly reactive intermediates that can bind covalently to critical components of the target cells and cause irreversible damage to the cells. The toxicity of organic solvents can be divided into two categories, (i) parent compound-induced toxicity, eg, anesthetic action which is a toxicity common to most of the fat-soluble volatile hydrocarbons (structure-nonspecific toxicity), and (ii) metabolite-mediated toxicity, eg, benzene-induced hematotoxicity and carbon tetrachloride-induced hepatotoxicity (structure-specific toxicity).

In the parent compound-induced toxicity, biotransformation accelerates the removal of toxic agents from the target organ. Thus it always means detoxication. In the metabolite-mediated toxicity, however, biotransformation results in the formation of more toxic metabolites. Hence the reaction is called bioactivation or biotoxification. Figure 5 illustrates the general pathway of organic solvents absorbed in the body. The

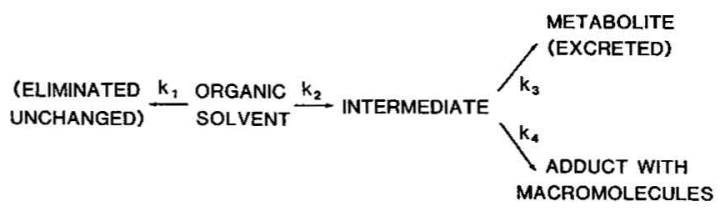

Figure 5. Relationship between biotransformation and the toxicity of organic solvents. $K_{i}(i=1-4)$ is the rate constant for each step. step with a rate constant $\mathrm{k}_{2}$ is a degradation reaction (phase 1 reaction) that requires energy to cleave the chemical bonds. Thus this step is considered to be ratelimiting in the overall metabolic processes. The step with $\mathrm{k}_{3}$ is a so-called phase 2 reaction or conjugation reaction and is normally considered to be a detoxication reaction. The resultant conjugates are excreted through the kidneys. The enzymes responsible for the degradation reaction are cytochrome P-450-related monooxygenases, which are localized at the smooth endoplasmic reticulum of animal cells.

The enzymes are found in high concentrations in the liver, but they also occur at lower concentrations in other organs. Among them, the lung assumes a special position in the metabolism of organic solvent vapors in that it is the first to come in contact with the inhaled chemicals. It must also be remembered that the lung is perfused by the entire cardiac output, whereas the liver receives one-fourth of the output. Table 4 shows the metabolic rates of various organic solvents measured with enzymes from rabbit lung and liver (unpublished data). The lung had much lower concentrations of enzymes than the liver, but the enzymes from the lung had much higher specific activities (activity per unit of cytochrome P-450 concentration) for all of the organic solvents studied. Especially, the activity for the aromatic solvents, except benzene, was amazingly high, almost 20 times as high as that of liver enzymes. Therefore, the lung is considered to contribute significantly to the total body clearance of organic solvent vapors in rabbits. In contrast to rabbits, however, rat lung enzymes had only negligible activity for these volatile substances in comparison with rat liver enzymes (data not shown). Whether the lung metabolism of man is close to that of rats or rabbits remains to be determined.

Table 4. Mean rates of metabolism in vitro of organic solvents in the livera and lung ${ }^{\mathrm{b}}$ of five male rabbits (unpublished data).

\begin{tabular}{|c|c|c|c|c|c|c|}
\hline \multirow{3}{*}{ Substrates } & \multicolumn{6}{|c|}{ Rates of metabolism } \\
\hline & \multicolumn{2}{|c|}{$\mathrm{nmol} \cdot \mathrm{g}^{-1} \cdot 10 \mathrm{~min}^{-1}$} & \multicolumn{2}{|c|}{$\mu \mathrm{mol} \cdot$ organ $^{-1} \cdot 10 \mathrm{~min}^{-1}$} & \multicolumn{2}{|c|}{$\begin{array}{c}\mathrm{nmol} \cdot \mathrm{nmol} \text { cytochrome } \\
\mathrm{P}-450^{-1} \cdot 10 \mathrm{~min}^{-1}\end{array}$} \\
\hline & Liver & Lung & Liver & Lung & Liver & Lung \\
\hline Benzene & 70.3 & 19.2 & 5.3 & 0.2 & 1.8 & 5.7 \\
\hline Toluene & 284.7 & 437.6 & 21.6 & 3.4 & 7.4 & 128.7 \\
\hline$m$-Xylene & 497.4 & 958.4 & 37.8 & 7.4 & 12.9 & 281.9 \\
\hline Ethylbenzene & 453.0 & 680.3 & 34.4 & 5.3 & 11.7 & 200.1 \\
\hline Propylbenzene & 740.2 & 1187.6 & 56.2 & 9.2 & 19.1 & 349.3 \\
\hline Cumene & 1021.1 & 1436.2 & 77.6 & 11.1 & 26.4 & 422.4 \\
\hline Styrene & 355.8 & 1134.6 & 27.0 & 8.8 & 9.2 & 333.7 \\
\hline Dichloromethane & 98.5 & 30.1 & 7.5 & 0.2 & 2.6 & 8.9 \\
\hline Chloroform & 97.6 & 40.9 & 7.4 & 0.3 & 2.5 & 12.0 \\
\hline Carbon tetrachloride & 10.8 & 9.8 & 0.8 & 0.1 & 0.3 & 2.9 \\
\hline 1,1-Dichloroethylene & 137.9 & 76.2 & 10.5 & 0.6 & 3.6 & 22.4 \\
\hline Trichloroethylene & 107.5 & 62.6 & 8.2 & 0.5 & 2.8 & 18.4 \\
\hline Monochlorobenzene & 101.1 & 112.3 & 7.7 & 0.9 & 2.6 & 33.0 \\
\hline
\end{tabular}

a Mean weight $76.0 \mathrm{~g}$, mean percentage of body weight 2.43 , mean amount of microsomal protein $(\mathrm{mg})$ per gram of tissue 28.0 , and mean amount of cytochrome P-450 (nmol) per milligram of protein 1.38.

b Mean weight $7.7 \mathrm{~g}$, mean percentage of body weight 0.25 , mean amount of protein $(\mathrm{mg})$ per gram of tissue 9.8 , and mean amount of cytochrome P-450 (nmol) per milligram of protein 0.35 . 


\section{Environmental factors that alter the metabolism and toxicity of organic solvents}

\section{Metabolic interaction among organic solvents}

Organic solvents are often used in mixed forms in manufacturing plants. Therefore, workers are often simultaneously exposed to more than one solvent vapor in the work environment. When two or more components enter a living body at the same time, interaction may take place at every site of absorption, excretion, metabolism, protein binding, and subcellular localization. We found that neither the solubility of benzene and toluene in blood nor their binding with bovine serum albumin was influenced by the presence of the other, suggesting that the absorption and distribution may not be significantly affected by their simultaneous presence (49). Concerning their in vivo and in vitro metabolism, however, toluene was a competitive inhibitor of benzene metabolism, and, conversely, benzene competitively inhibited the side-chain hydroxylation of toluene (49). The same line of metabolic interaction was also observed between benzene and $m$-xylene and between toluene and $m$-xylene (unpublished data). Several investigators have demonstrated that coadministration of toluene with benzene protects animals from benzene-induced hematotoxicity $(4,22,63)$. Therefore, the possibility of metabolic interaction must always be kept in mind in the toxicologic evaluation of mixed organic solvent vapors. However, the interactions are characteristically exhibited only at high concentrations, and the effect of such interaction on humans, who are normally exposed to low concentrations, may be disregarded except under unusual circumstances (49).

\section{Food consumption - Caloric intake}

One day of complete food deprivation invariably accelerated the hepatic metabolism of 21 aromatic or chlorinated volatile hydrocarbons in rats (38). Fasting over a period of $2-3 \mathrm{~d}$ did not augment the increase caused by 1-d fasting. One-day food deprivation caused no change in the microsomal protein and cytochrome P-450 contents. The liver weight itself decreased by about $20 \%$, and thus the amount of the protein or the cytochrome per liver, ie, the amount per rat, decreased accordingly. It is remarkable that an increase in metabolism was still noted even when the rate was expressed in terms of whole liver, despite the diminished size of the liver. This increase was confirmed to occur not only in in vitro but also in in vivo systems. In an experiment in which rats were exposed to trichloroethylene (38), the compound was shown to disappear more rapidly from the blood of 1-d fasted rats than from the blood of normally fed rats. In addition the fasted animals excreted a much greater amount of trichloroethylene metabolites, total trichloro compounds, into the urine than did the fed animals.
Food restriction increased the rate of toluene and trichloroethylene metabolism in vitro almost linearly with the decrease in food intake (figure 6); this finding suggests that the amount of food consumed on the day before toxicity testing can affect the metabolism of a variety of organic solvents, and hence produce a considerable effect on toxicity (35). In fact, 1-d food restriction enhanced carbon tetrachloride-induced hepatotoxicity in a dose-related manner, as evidenced by a linear increase in plasma glutamate-pyruvate transaminase (GPT) and glutamate-oxalacetate transaminase (GOT) activities with a decrease in food consumption (27).

\section{Dietary carbohydrates}

The general belief has so far been that protein is the most important nutrient in regulating the metabolism and toxicity of chemical substances $(7,8)$. A proteinrich diet is known to exacerbate carbon tetrachlorideor dimethylnitrosamine-induced hepatotoxicity by accelerating transformation of these chemicals to their respective reactive intermediates $(31,32)$. In earlier experiments, however, the protein content in a diet was varied at the expense of carbohydrates to make the diet isocaloric. (A high-protein diet was nothing but a lowcarbohydrate diet, and a low-protein diet contained excessive amounts of carbohydrates.) Our metabolism study (35) clearly demonstrated that it is carbohydrates, not protein or fat, that regulates the hepatic metabolism of various organic solvents. The rate of metabolism increased linearly with decreasing carbohydrate intake independently of protein or fat intake. This observation is exemplified by two important organic solvents, toluene and trichloroethylene, in figure 7. One-day feeding of rats with a carbohydrate-free diet containing adequate amounts of protein, fat and other essential nutrients greatly enhanced the metabolism. The enhancement was almost comparable to that achieved by $1-\mathrm{d}$ complete food deprivation. This finding is not at all in conflict with the earlier findings that a high-protein diet increases, and a low-protein diet decreases, the metabolism of some foreign compounds. What it really means, however, is completely

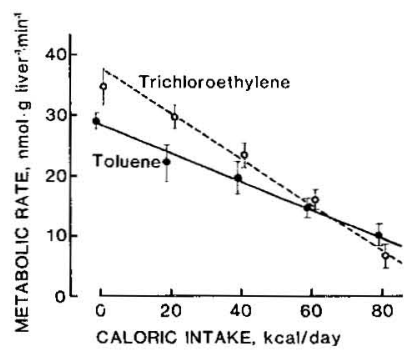

Figure 6. Effects of food consumption on the metabolism of trichloroethylene and toluene (35). Rats were given various amounts of food of the same composition on the day before the metabolism assay. $(1 \mathrm{kcal}=4.2 \mathrm{~kJ})$ 

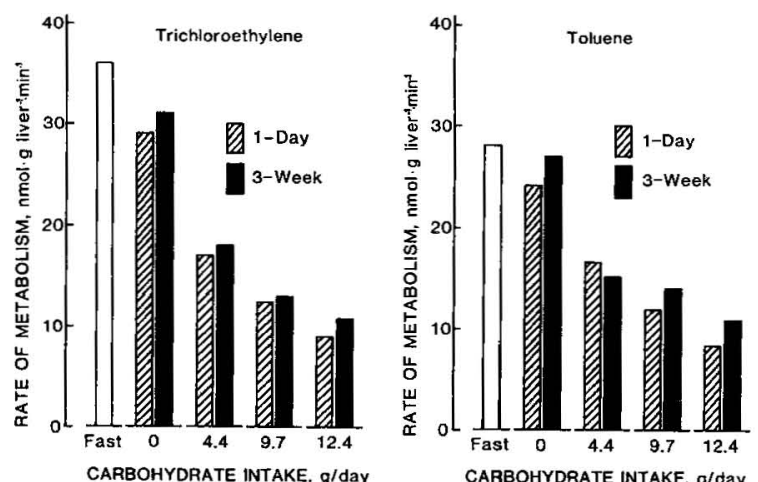

Figure 7. Effects of carbohydrate intake on the metabolism of trichloroethylene and toluene (35). Rats were fed test diets containing various amounts of carbohydrate (sucrose) on the day before sacrifice only (1-Day) or every day for three weeks prior to sacrifice (3-Week). All the diets were kept isocaloric in that fat was replaced with sucrose. This effect of lowcarbohydrate intake was also confirmed by another trial in which only carbohydrate intake was varied, both protein and fat intake being fixed.
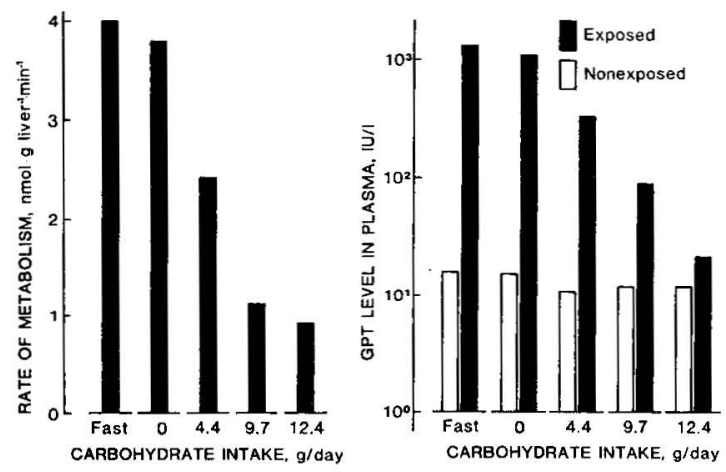

Figure 8. Effects of carbohydrate intake on the metabolism and toxicity of carbon tetrachloride (35). Rats were fed isocaIoric test diets containing various amounts of sucrose on the day before the metabolism assay (left). The rats that had received the test diets on the preceding day were exposed to $400 \mathrm{ppm}$ of carbon tetrachloride for $4 \mathrm{~h}$, and the plasma glutamate-pyruvate transaminase (GPT) level was measured $20 \mathrm{~h}$ after the exposure (right).

different; it is not protein but carbohydrates in the diet that actually determines the hepatic metabolism.

This finding was further supported by a study of the effect of dietary carbohydrates on carbon tetrachloride-induced liver damage (35), as shown in figure 8. Carbohydrate consumption exerted a great influence on carbon tetrachloride hepatotoxicity. The lower the consumption, the more severe the damage to the liver. A carbohydrate-free diet containing the other nutrients in adequate amounts caused markedly severe liver injury, the degree of which was almost as severe as that caused by 1-d food deprivation. The severity closely paralleled the extent of carbon tetrachloride metabolism in the liver. Since carbon tetrachloride must be enzymatically activated to become cytotoxic, we can say that a low-carbohydrate diet potentiates the hepatotoxicity by accelerating the conversion of this chemical into reactive intermediates.

A three-week caloric restriction or lowered carbohydrate consumption did not augment the effect of 1-d dietary manipulation in rats (figure 7) (35). This finding suggests again that the amount or composition of food consumed on the day before toxicity testing produces substantial effects on the metabolism and toxicity of organic solvents.

Dietary habits differ considerably among individuals. Some eat a lot, some go on a diet, and some have an unbalanced diet. This dietary divergency may play a role in producing individual differences in susceptibility to chemical toxicity.

\section{Alcohol ingestion}

Ethanol is the only environmental chemical that man consumes in multigram quantities. It is not rare that industrial workers with the aftereffects of the night's drink are exposed to chemicals in their work environment. Therefore, it is very important to clarify the effect of ethanol consumption on the metabolism and toxicity of chemical substances.

Ethanol has been shown to produce two mutually opposing effects on the metabolism of organic solvents, ie, stimulation and inhibition (55). Which one predominated over the other depended on the time that elapsed after ethanol ingestion. In the early period when ethanol existed in high concentrations, it preferentially acted as an inhibitor. On the contrary, when ethanol was disappearing from the body, ie, 16 to $18 \mathrm{~h}$ after ingestion, the metabolism-enhancing effect became maximal, while the inhibitory effect became minimal.

It is remarkable that the greatly enhanced metabolism of organic solvents following three weeks of daily ethanol consumption returned to the normal level after a 1-d withdrawal of ethanol (54). An acute dose of ethanol, $4 \mathrm{~g} / \mathrm{kg}$, increased the metabolism of both toluene and trichloroethylene in rat liver two- to threefold $18 \mathrm{~h}$ later, but the effect had almost disappeared $36 \mathrm{~h}$ after the ethanol administration (55). These findings indicate that recently ingested ethanol plays an important role in enhancing the hepatic metabolism of these substances.

A single dose of ethanol, which induced the enhanced metabolism, increased neither the microsomal protein nor cytochrome P-450 content (55). Moreover, even prolonged ethanol administration produced only a slight increase in these enzymic parameters (54). These findings give the impression that the ethanol-induced alteration of the metabolism of organic solvents may be different from the enzyme induction produced by well-known enzyme inducers such as phenobarbital, but may resemble the effect of food deprivation or lowered carbohydrate intake. This possibility is discussed later in more detail. 


\section{Interaction of carbohydrates with ethanol}

Dietary carbohydrate intake at the time of ethanol ingestion had a marked influence on the metabolismenhancing effect of ethanol (56). A decrease (increase) in dietary carbohydrate intake augmented (suppressed) the action of ethanol dose-dependently. A combination of ethanol with a carbohydrate-deficient diet markedly enhanced the metabolism of various organic solvents without exception. Figure 9 shows the results with toluene and trichloroethylene as representatives of the observations. The combined effect cannot be explained as mere additive since the value for the combination is much greater than the sum of the effects produced by either treatment alone. In addition, only when ethanol was consumed with a low-carbohydrate diet, were the liver microsomal protein and cytochrome P-450 contents significantly increased. This apparently synergistic effect of lowered carbohydrate intake with ethanol is particularly interesting because, when drinking alcoholic beverages, people are often told to be moderate in their consumption of carbohydrates because ethanol $[7 \mathrm{kcal} / \mathrm{g}(29.4 \mathrm{~kJ} / \mathrm{g})]$ is a much better energy source than carbohydrates $[4 \mathrm{kcal} / \mathrm{g}(16.8$ $\mathrm{kJ} / \mathrm{g})]$.

Phenobarbital as a clue to the underlying mechanism of the dietary and ethanol-induced alteration of the metabolism and toxicity of organic solvents

Although causing a marked increase in microsomal protein or cytochrome P-450 content, phenobarbital was found to increase the metabolism of only a limited number of organic solvents (50). In other words, phenobarbital-induced enzymes had a distinct substrate specificity. Phenobarbital induced a marked increase in the metabolism of toluene and styrene, but did not affect the metabolism of benzene and 1,2-dichloroethane. It is remarkable that, when calculated on the basis of the unit concentration of cytochrome P-450, the rates of the metabolism of benzene and 1,2dichloroethane distinctly decreased after treatment with phenobarbital (figure 10). The effect of polychlorinated biphenyls on the metabolism of organic solvents was similar to that of phenobarbital. 3-Methylcholanthrene treatment exerted no influence on the metabolism of any of the organic solvents studied. We can say that the liver enzymes induced by phenobarbital, polychlorinated biphenyls, or 3methylcholanthrene have a strict substrate specificity toward organic solvent metabolism, whereas the enzyme stimulation by ethanol consumption or dietary manipulation is substrate nonspecific. It must be remembered that this conclusion may not always apply to the metabolism of foreign compounds other than organic solvents. In fact, neither ethanol, nor a lowcarbohydrate diet, nor their combination affected the rat liver metabolism of polycyclic aromatic hydrocarbons such as 3,4-benzopyrene and 7,12-dimethylbenzanthracene, whereas these treatments markedly
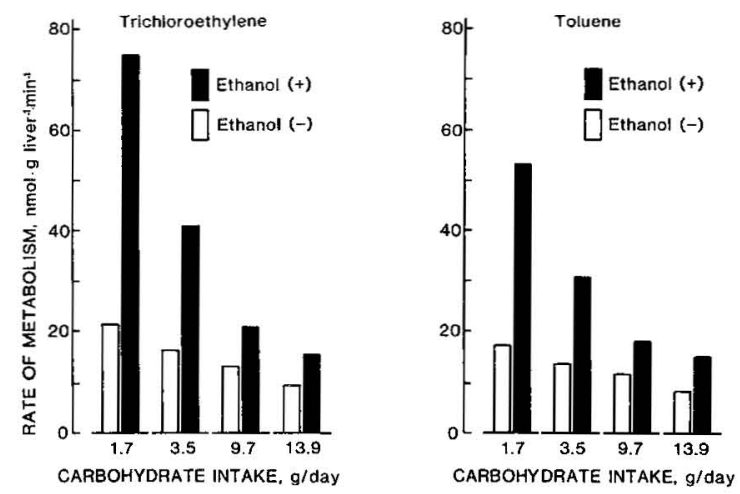

Figure 9. Interaction between ethanol and carbohydrate on the metabolism of trichloroethylene and toluene (56). Rats were given $2.0 \mathrm{~g}$ of ethanol every day for three weeks in combination with diets containing various amounts of carbohydrate (sucrose). The intake of other nutrients was kept constant.

increased the metabolism of dimethylnitrosamine and diethylnitrosamine $(39,57)$. It seems reasonable to conclude that the dietary and ethanol-induced alteration of metabolism and toxicity is limited to lowmolecular weight substances with volatility.

As expected, lowered carbohydrate intake and ethanol consumption rendered rats more susceptible to the hepatotoxic effect of carbon tetrachloride (35, $55,56)$. In particular, a combination of ethanol with a low-carbohydrate diet markedly potentiated the hepatotoxicity as evidenced by a remarkable increase in the plasma GOT and GPT levels (56). However, the results with phenobarbital treatment were not in agreement with our belief that the more extensively carbon tetrachloride is metabolized, the more seriously the liver is affected. Phenobarbital, which produced only a minor increase in carbon tetrachloride metabolism, caused severe liver damage (50). Our enzyme assay, conducted under an atmosphere of nitrogen gas, revealed that the metabolism of carbon tetrachloride with enzymes from rats treated with phenobarbital proceeds rapidly under anaerobic conditions. The rate of anaerobic metabolism with the enzymes far exceeded that determined aerobically with enzymes from rats administered ethanol in combination with a lowcarbohydrate diet (50). Therefore, phenobarbital treatment may accelerate the metabolic activation of carbon tetrachloride in vivo $\left[\mathrm{O}_{2}\right.$ tension, $40 \mathrm{~mm} \mathrm{Hg}$ $(5.3 \mathrm{kPa})$ or lower], which proceeds by reductive cytochrome P-450-dependent pathways, more than is indicated by the assay in vitro [150 $\mathrm{mm} \mathrm{Hg}(20 \mathrm{kPa})]$. Thus, an anaerobic metabolism assay is also needed to predict accurately the disposition of carbon tetrachloride in a living system.

The effects of phenobarbital treatment on the metabolism of benzene are conflicting. Many investigators have reported that benzene hydroxylase activity was increased by treatment of the animals with phenobarbital $(10,19,59,62)$, but others, including 

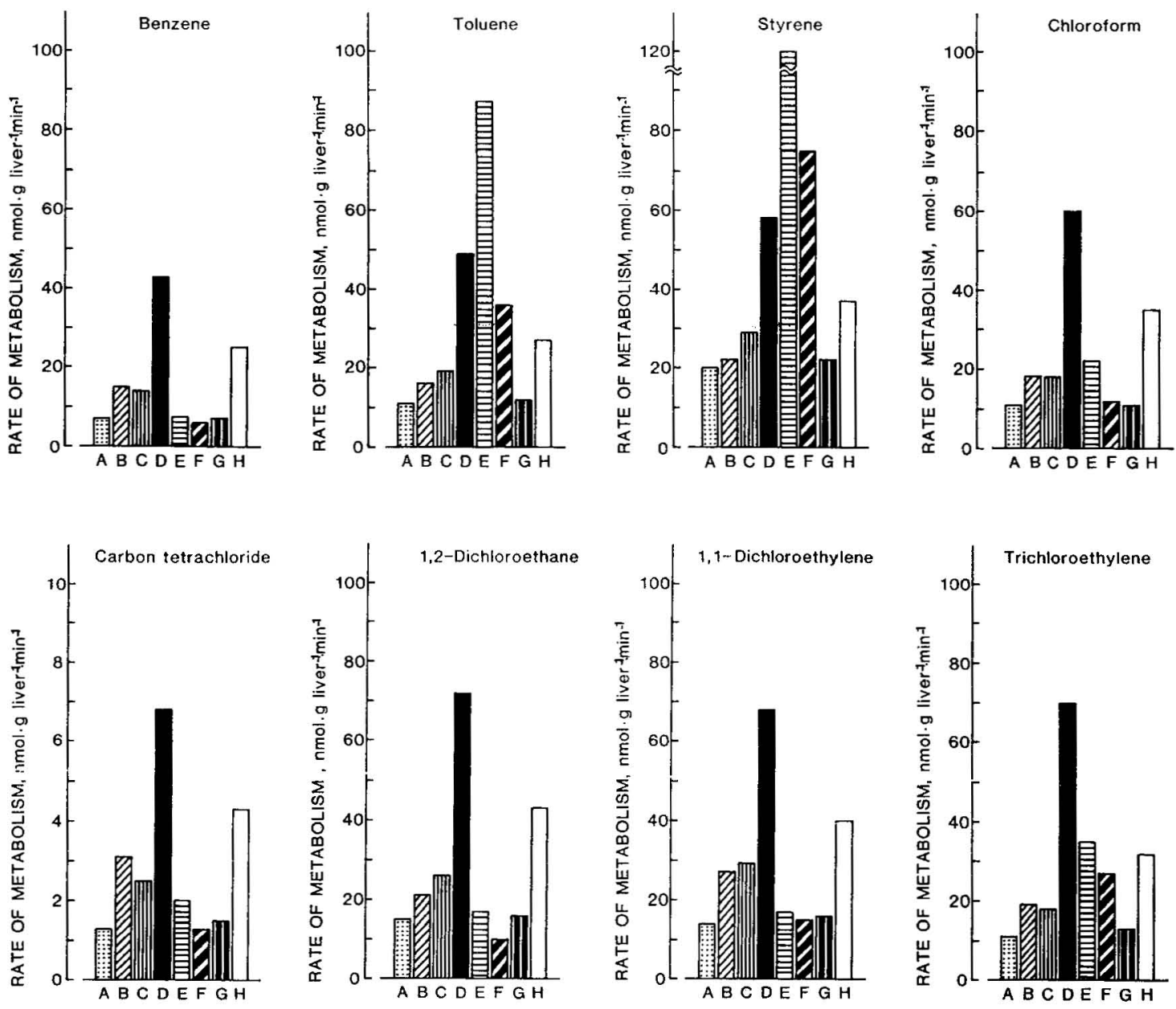

Figure 10. Metabolism of organic solvents in the liver of rats maintained on various dietary regimens $(50)$. $[A=$ moderatecarbohydrate diet (carbohydrate $9.72 \mathrm{~g} / \mathrm{d}$ ), $\mathrm{B}=10 \mathrm{w}$-carbohydrate diet (carbohydrate $1.74 \mathrm{~g} / \mathrm{d}$ ), $\mathrm{C}=$ low-carbohydrate diet + ethanol $(2 \mathrm{~g} / \mathrm{d}), \mathrm{D}=$ moderate-carbohydrate diet + ethanol $(2 \mathrm{~g} / \mathrm{d}), \mathrm{E}=$ moderate-carbohydrate diet + phenobarbital $\left(80 \mathrm{mg} \cdot \mathrm{kg}^{-1} \cdot \mathrm{d}^{-1}\right.$ for $3 \mathrm{~d}$, perorally), $\mathrm{F}=$ moderate-carbohydrate diet + polychlorinated biphenyl (a single dose of $500 \mathrm{mg} / \mathrm{kg}$, intraperitoneally), $\mathrm{G}=$ moderate-carbohydrate diet +3 -methylcholanthrene $(20 \mathrm{mg} / \mathrm{d}$ for $3 \mathrm{~d}$, perorally), $\mathrm{H}=$ rats on a moderatecarbohydrate diet, but deprived of food on the day before being killed]

us, reported a negative effect $(18,50)$. This apparent discrepancy may be due to the difference in the substrate concentrations used in the metabolism study. For example, we used a benzene concentration of $35.3 \mu \mathrm{M}$ (50), whereas much higher concentrations of 2.3 to $4.5 \mathrm{mM}$ were employed in one study reporting a "positive" effect (59). Post $\&$ Snyder (42) were the first to report that the liver enzymes responsible for benzene hydroxylation consist of at least two forms of enzymes, each with a different catalytic property toward benzene. One form is active at all substrate concentrations, and the other is preferentially active in microsomes from phenobarbital-treated rats at benzene concentrations above $0.8 \mathrm{mM}$. We have recently confirmed this finding, and our results have revealed that a liver microsomal preparation from normally fed rats contains two forms of isoenzymes with different $\mathrm{Km}$ values toward benzene, ie, 0.01 and $0.1 \mathrm{mM}$ (36).
The isoenzyme with a $\mathrm{Km}$ of $0.01 \mathrm{mM}$ disappeared following 1-d food deprivation, but the deprivation increased the activity (VTax) of the other isoenzyme that had a $K m$ of $0.1 \mathrm{mM}$. Ethanol treatment markedly increased the activity of both enzymes existing normally in rat liver. On the other hand, treatment with phenobarbital induced the synthesis of another isoenzyme with a high $K m$ value of $4.5 \mathrm{mM}$, which was indistinct in the microsomes from untreated rats. Accordingly, food deprivation and ethanol consumption increased the metabolism of benzene at various substrate concentrations, whereas treatment with phenobarbital did not increase the metabolism until the concentration was as high as $1.0 \mathrm{mM}$. Considering man's actual level of exposure to benzene in his work environment, it is needless to say that the low $\mathrm{Km}$ form of isoenzymes is more important than the high $\mathrm{Km}$ form. In fact, the highest blood concentration of ben- 
zene achieved by an experimental inhalation exposure of rats to $500 \mathrm{ppm}$ of benzene was between 0.1 and $0.15 \mathrm{mM}$ (37).

In accordance with these findings in metabolism studies in vitro, our exposure experiment with rats revealed that ethanol increases benzene metabolism in vivo as evidenced by the accelerated disappearance of benzene from the blood, as well as by an elevated urinary excretion of phenol, whereas phenobarbital produces little or no significant influence on the metabolism (37). In agreement with the concept of Sammet et al (44) that hepatic metabolism plays a very important role in producing benzene-induced hemopoietic disorder, ethanol consumption potentiated the toxicity of benzene $(37,58)$. In contrast, phenobarbital produced a protective effect on toxicity $(21,37)$.

An isoenzyme of cytochrome P-450 with physicochemical and catalytic properties distinct from those induced by phenobarbital or 3-methylcholanthrene has been isolated and purified from the liver of ethanoltreated animals $(9,26,40)$. A series of metabolism studies in our laboratory suggests that ethanol, especially when administered concomitantly with a low-carbohydrate diet, induces a form of cytochrome $\mathrm{P}-450$ that is catalytically active for chemicals such as, eg, organic solvents, as characterized by volatility and low molecular weight. Similarly, food deprivation or lowered carbohydrate intake may stimulate the synthesis of a certain species of enzymes having a specifically high activity for volatile chemicals with low molecular weight (61) or may stimulate the enzyme activity by modifying the membrane environment or by displacing other endogenous or exogenous substrates already bound to the enzymes (23).

It is well-known that treatment with phenobarbital, polychlorinated biphenyls or 3-methylcholanthrene enhances the activity of enzymes, such as glucuronyl transferase and glutathione-S-transferase, involved in phase 2 reactions $(5,24,60,64)$. However, neither food deprivation nor restricted carbohydrate intake nor ethanol consumption produced any significant effect on the activity of these enzymes (50). As discussed before, phase 1 reactions (the step with a rate constant $k_{2}$ in figure 5) can sometimes result in the production of highly reactive metabolites, some of which may covalently bind to critical components of the cell, whereas others may undergo conjugation reactions $\left(k_{3}\right)$ and result in detoxication. Thus the amount of chemical that binds to macromolecules depends on the relative rates of these reactions rather than on the absolute rate of either. If $A_{0}$ is the amount of a chemical absorbed in a body, then the amount of the chemical that eventually undergoes adduct formation with critical macromolecules is expressed as

$$
\frac{k_{2}}{k_{1}+k_{2}} \cdot \frac{k_{4}}{k_{3}+k_{4}} A_{0} \text {. }
$$

Therefore, changes in nutrition or ethanol consump- tion, which accelerate $k_{2}$ but do not affect $k_{3}$, may lead more directly to an increase in covalent binding to macromolecules than would phenobarbital treatment, which enhances $k_{3}$ with little or no influence on $k_{2}$. This phenomenon explains more clearly why ethanol aggravates benzene-induced hemopoietic disorders, while treatment with phenobarbital protects animals from the injury.

However, the influence of caloric restriction on the toxicity of chemical compounds is more complicated because the restriction reduces the body fat content and therefore affects the pharmacokinetic profile of highly lipophilic substances like benzene. In fact, foodrestricted rats eliminated benzene more rapidly than did normally fed rats. This occurrence may explain why food restriction prevents benzene toxicity despite its ability to enhance benzene metabolism (52).

\section{References}

1. Astrand I. Uptake of solvent in the blood and tissues of man: A review. Scand J Work Environ Health 1 (1975) 199-218.

2. Ástrand I. Effect of physical exercise on uptake, distribution and elimination of vapor in man. In: FiserovaBergerova $\mathrm{V}$, ed. Modeling of inhalation exposure to vapors: Uptake, distribution, and elimination. Volume 2. CRC Press, Boca Raton FL 1983, pp 107-130.

3. American Conference of Governmental Industrial Hygienists. Threshold limit values for chemical substances and physical agents in the work environment and biological exposure indices with intended changes for 1984-85. Cincinnati, OH 1984-1985.

4. Andrews LS, Lee EW, Witmer CM, Kocsis JJ, Snyder R. Effects of toluene on the metabolism, disposition and hemopoietic toxicity of ${ }^{3} \mathrm{H}$-benzene. Biochem Pharmacol 26 (1977) 293-300.

5. Bock KW, Fröhling W, Remmer H, Rexer B. Effects of phenobarbital and 3-methylcholanthrene on substrate specificity of rat liver microsomal UDP-glucuronyltransferase. Biochem Biophys Acta 327 (1973) 45-56.

6. Browning E. Toxicity and metabolism of industrial solvents. Elsevier, Amsterdam, London, New York 1965 , pp 3-31.

7. Campbell TC. Effects of dietary protein on drug metabolism. In: Hathcock JN, Coon J, ed. Nutrition and drug interactions. Academic Press, New York NY 1978, pp 409-422.

8. Campbell TC, Hayes JR. Role of nutrition in the drugmetabolizing enzyme system. Pharmacol Rev 26 (1974) $171-197$.

9. Comai K, Gaylor JL. Existence and separation of three forms of cytochrome P-450 from rat liver microsomes. J Biol Chem 248 (1973) 4947-4955.

10. Drew RT, Fouts JR. The lack of effects of pretreatment with phenobarbital and chloropromazine on the acute toxicity of benzene in rats. Toxicol Appl Pharmacol 27 (1974) $183-193$.

11. Dutkiewicz T, Tyras H. Skin absorption of toluene, styrene, and xylene by man. Br J Ind Med 25 (1968) 243.

12. Dutkiewicz $T$, Tyras $H$. The quantitative estimation of toluene skin absorption in man. Arch Gewerbepath Gewergehyg 24 (1968) 253-257.

13. Eger EI II. A mathematical model of uptake and distribution. In: Papper EM, Kitz RJ, ed. Uptake and distribution of anesthetic agents. McGraw-Hill, New York, NY 1963, pp 72-87. 
14. Engstrom K, Husman K, Riihimaki V. Percutaneous absorption of m-xylene in man. Int Arch Occup Environ Health 39 (1977) 181-189.

15. Fiserova-Bergerova V. Physiological models for pulmonary administration and elimination of inert vapors and gases. In: Fiserova-Bergerova V, ed. Modeling of inhalation exposure to vapors: Uptake, distribution, and elimination. Volume 1. CRC Press, Boca Raton, FL 1983, pp 73-100.

16. Gehring PJ. Hepatotoxic potency of various chlorinated hydrocarbon vapors related to their narcotic and lethal potencies in mouse. Toxicol Appl Pharmacol 13 (1968) 287-298.

17. Gillette JR, Mitchell JR, Brodie BB. Biochemical mechanisms of drug toxicity. Annu Rev Pharmacol 14 (1974) $271-288$.

18. Gonasum LM, Witmer C, Kocsis JJ, Snyder R. Benzene metabolism in mouse liver microsomes. Toxicol Appl Pharmacol 26 (1973) 398-406.

19. Gut I. Effect of phenobarbital treatment on in vitro enzyme kinetics and in vivo biotransformation of benzene in the rat. Arch Toxicol 35 (1976) 195-206.

20. Hansch C. Quantitative structure-activity relationship in drug design. In: Ariens EJ, ed. Drug design. Volume 1. Academic Press, New York, London 1971, pp $271-342$.

21. Ikeda $\mathbf{M}$, Ohtsuji $\mathrm{H}$. Phenobarbital-induced protection against toxicity of toluene and benzene in the rat. Toxicol Appl Pharmacol 20 (1971) 30-43.

22. Ikeda $\mathbf{M}$, Ohtsuji $\mathrm{H}$, Imamura $\mathrm{T}$. In vivo suppression of benzene and styrene oxidation by coadministered toluene and effects of phenobarbital. Xenobiotica 2 (1972) $101-106$.

23. Ioannides C, Parke DV. The effect of ethanol administration on drug oxidations and possible mechanism of ethanol-barbiturate interactions. Biochem Soc Trans 1 (1973) $716-720$.

24. Kaplowitz N, Kuhlenkamp J, Clifton G. Drug induction of hepatic glutathione-S-transferases in male and female rats. Biochem J 146 (1975) 351-356.

25. Klaassen CD, Plaa GL. Comparison of the biochemical alterations elicited in livers from rats treated with carbon tetrachloride, chloroform, 1,1,2-trichloroethane and 1,1,1-trichloroethane. Biochem Pharmacol 18 (1969) 2019-2027.

26. Koop DR, Morgan ET, Tarr GE, Coon MJ. Purification and characterization of a unique isozyme of cytochrome P-450 from liver microsomes of ethanoltreated rabbits. J Biol Chem 257 (1982) 8472-8480.

27. Koyama Y, Sato A. Effects of one-day food restriction on the metabolism and toxicity of organic solvents in rats [in Japanese]. Jpn J Ind Health 28 (1986) 96-100. (English summary).

28. Larson CP Jr. Solubility and partition coefficients. In: Papper EM, Kitz RJ, ed. Uptake and distribution of anesthetic agents. McGraw-Hill, New York, NY 1963, pp 5-16.

29. Lauwerys RR, Dath T, Lachapelle JM, Buchet JP, Roels $H$. The influence of two barrier creams on the percutaneous absorption of $\mathrm{m}$-xylene in man. J Occup Med 20 (1978) 17-20.

30. Levy G, Gibaldi M. Pharmacokinetics of drug action. Annu Rev Pharmacol 12 (1972) 85-98.

31. McLean AEM, McLean EK. The effect of diet and 1,1,1-trichloro-2,2-bis( $p$-chlorophenyl)ethane (DDT) on microsomal hydroxylating enzymes and on sensitivity of rats to carbon tetrachloride poisoning. Biochem J 100 (1966) 564-571.

32. Mclean AEM, McLean EK. Diet and toxicity. Br Med Bull 25 (1969) 278-281.

33. Miller KW, Paton WDM, Smith EB, Smith RA. Physicochemical approaches to the mode of action of general anesthetics. Anesthesiology 36 (1972) 339-351.
34. Morgan A, Black A, Belcher DR. The excretion in breach of some aliphatic halogenated hydrocarbons following administration by inhalation. Ann Occup Hyg 13 (1970) 219-233.

35. Nakajima T, Koyama Y, Sato A. Dietary modification of metabolism and toxicity of chemical substances with special reference to carbohydrate. Biochem Pharmacol 31 (1982) 1005-1011.

36. Nakajima T, Okino T, Sato A. Kinetic studies on benzene metabolism in rat liver - Possible presence of three forms of benzene-metabolizing enzymes in the liver. Biochem Pharmacol (in press).

37. Nakajima T, Okuyama S, Yonekura I, Sato A. Effects of ethanol and phenobarbital administration on the metabolism and toxicity of benzene. Chem-Biol Interact 55 (1985) 23-38.

38. Nakajima T, Sato A. Enhanced activity of liver drugmetabolizing enzymes for aromatic and chlorinated hydrocarbons following food deprivation. Toxicol Appl Pharmacol 50 (1979) 549-556.

39. Nakajima T, Yonekura I, Sato A. A simple method to evaluate liver microsomal enzyme activity for phenol metabolism with a high-performance liquid chromatograph. Toxicol Lett 29 (1985) 11-15.

40. Ohnishi K, Lieber CS. Reconstitution of the microsomal ethanol-oxidizing system: Qualitative and quantitative changes of cytochrome P-450 after chronic ethanol consumption. J Biol Chem 252 (1977) 7124-7131.

41. Piotrowski JK. Quantitative estimate of the absorption of toluene in people. Med Pracy 18 (1967) 214-223.

42. Post GB, Snyder R. Effects of enzyme induction on microsomal benzene metabolism. J Toxicol Environ Health 11 (1983) 811-825.

43. Riihimaki V, Pfaffli P. Percutaneous absorption of solvent vapors in man. Scand $\mathbf{J}$ Work Environ Health 4 (1978) $73-85$.

44. Sammet D, Lee EW, Kocsis JJ, Snyder R. Partial hepatectomy reduces both metabolism and toxicity of benzene. J Toxicol Environ Health 5 (1979) 785-792.

45. Sato A, Nakajima T. Differences following skin or inhalation exposure in the absorption and excretion kinetics of trichloroethylene and toluene. $\mathrm{Br} \mathrm{J}$ Ind Med 35 (1978) 43-49.

46. Sato A, Nakajima T. Partition coefficients of some aromatic hydrocarbons and ketones in water, blood and oil. Br J Ind Med 36 (1979) 231-234.

47. Sato A, Nakajima T. A structure-activity relationship of some chlorinated hydrocarbons. Arch Environ Health 34 (1979) 69-75.

48. Sato A, Nakajima T. A vial-equilibration method to evaluate the drug-metabolizing enzyme activity for volatile hydrocarbons. Toxicol Appl Pharmacol 47 (1979) 41-46.

49. Sato A, Nakajima T. Dose-dependent metabolic interaction between benzene and toluene in vivo and in vitro. Toxicol Appl Pharmacol 48 (1979) 249-256.

50. Sato A, Nakajima T. Enhanced metabolism of volatile hydrocarbons in rat liver following food deprivation, restricted carbohydrate intake, and administration of ethanol, phenobarbital, polychlorinated biphenyl and 3-methylcholanthrene: A comparative study. Xenobiotica 15 (1985) 67-75.

51. Sato A, Nakajima T, Fujiwara Y, Hirosawa K. Pharmacokinetics of benzene and toluene. Int Arch Arbeitsmed 33 (1974) 169-182.

52. Sato A, Nakajima T, Fujiwara Y, Murayama N. Kinetic studies on sex difference in susceptibility to chronic benzene intoxication with special reference to body fat content. Br J Ind Med 32 (1975) 321-328.

53. Sato A, Nakajima T, Fujiwara Y, Murayama N. A pharmacokinetic model to study the excretion of trichloroethylene and its metabolites after an inhalation exposure. Br J Ind Med 34 (1977) 56-63. 
54. Sato A, Nakajima T, Koyama X. Effects of chronic ethanol consumption on hepatic metabolism of aromatic and chlorinated hydrocarbons in rats. $\mathrm{Br} \mathrm{J}$ Ind Med 37 (1980) 382-386.

55. Sato A, Nakajima T, Koyama Y. Dose-related effects of a single dose of ethanol on the metabolism in rat liver of some aromatic and chlorinated hydrocarbons. Toxicol Appl Pharmacol 60 (1981) 8-15.

56. Sato A, Nakajima $T$, Koyama $Y$. Interaction between ethanol and carbohydrate on the metabolism in rat liver of aromatic and chlorinated hydrocarbons. Toxicol Appl Pharmacol 68 (1983) 242-249.

57. Sato A, Yonekura I, Nakajima T, Ohta S, Shirai T, Ito N. Augmentation of ethanol-induced enhancement of dimethylnitrosamine and diethylnitrosamine metabolism by lowered carbohydrate intake. Jpn J Cancer Res 77 (1986) $125-130$

58. Snyder CA, Baarson KA, Goldstein BD, Albert RE. Ingestion of ethanol increases the hematotoxicity of inhaled benzene in C57B1 mice. Bull Environ Contam Toxicol 27 (1980) 175-180.

59. Snyder R, Uzuki F, Gonasum LM, Bromfeld E, Wells A. The metabolism of benzene in vitro. Toxicol Appl Pharmacol 11 (1967) 346-360.
60. Thompson TN, Watkins JB, Gregus Z, Klaassen CD. Effect of microsomal enzyme inducers on the soluble enzymes of hepatic phase II biotransformation. Toxicol Appl Pharmacol 66 (1982) 400-408.

61. Tu YY, Yang CS. High-affinity nitrosamine dealkylase system in rat liver microsomes and its induction by fasting. Cancer Res 43 (1983) 623-629.

62. Tunek A, Oesch F. Unique behavior of benzene monooxygenase: Activation by detergent and different properties of benzene- and phenobarbital-induced monooxygenase activities. Biochem Pharmacol 28 (1979) $3425-3429$.

63. Tunek A, Olofsson T, Berlin M. Toxic effects of benzene and benzene metabolites on granulopoietic stem cells and bone marrow cellularity in mice. Toxicol Appl Pharmacol 59 (1981) 149-156.

64. Vainio H. Enhancement of microsomal drug oxidation and glucuronidation in rat liver by an environmental chemical, polychlorinated biphenyl. Chem-Biol Interact 9 (1974) $379-387$.

Received for publication: 15 September 1986 